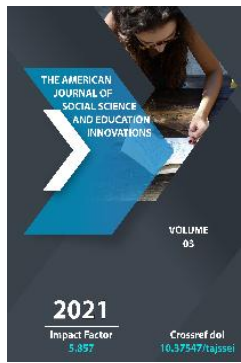

\title{
Renaissance And Renaissance Philosophical Texts Through The Prism Of Historical Approach
}

Denis Bakhtiyorovich Sadullaev

English Chair Bukhara State Medical Institute, Uzbekistan

Journal Website:

http://theamericanjour

nals.com/index.php/taj

ssei

Copyright: Original content from this work may be used under the terms of the creative commons attributes 4.0 licence.

\section{ABSTRACT}

The article is devoted to some aspects of the functional specificity of lexical borrowings - neologisms - that have found their vivid reflection in the works and philosophical thought of the European era and, in particular, the English Renaissance, represented by its brightest representatives such as Thomas More, Francis Bacon, John Donne, Shakespeare and others. The authors consider this problem in a synchronous-diachronous cut and in the light of the new socio-political situations of the century of the English Renaissance and in the light of the evolutionary process of the formation of the English nation and the norms of the literary English language, which continued intensively in the 11th century, which led to the further growth and spread of both oral, and written national literary language.

\section{KEYWORDS}

Revival, synchronous-diachronic realms, abstract, neologism, historical approach.

\section{INTRODUCTION}


The element of the philosophical thought of the Renaissance is one of those features that especially explicitly associate it with the era

that gave birth to the titans of philosophical and literary thought and imagination. After all, the entire Renaissance, and especially the later Renaissance (XVI-XVII centuries), is marked, as you know, by an appeal to general questions of being $[1$, p. 3-7] ,. The growing and bursting social crises, which marked the development of the era, led to the fact that not only for a small circle of the elite, but also for many commons (commoners), the usual ideas about the world and its laws collapsed [2, p. 222]. Most often this manifested itself in the form of breaking and changing religious ideas, in the struggle of ideas put forward by different directions of the era. But these ideas themselves, to one degree or another, also touched upon general problems of a philosophical nature, and then, on a large scale, there was going beyond the religious, theological framework - general questions of being were raised, and often in the traditions of ancient philosophy, which became the dominant trend of the Renaissance [3, p. 496].

Philosophical thought in various, and sometimes even in bizarre forms became the property of the masses, truly democratized, but soon after the victory of the CounterReformation in one part of Europe and the complete stagnation of the Reformation in another, the wave of philosophical thought among the people subsided, it left its indelible traces. in particular, in the best works of Renaissance literature, and, above all, in Shakespeare. This era in the history of England was a period of profound socio-economic and political changes, when the emerging new order takes over the old, feudal-serf. The process of the formation of the English nation, which continued intensively in the XYI century [Stupin 1989; Shadmanov 2019], led to the further growth and spread of both oral and written national languages. As a written language, the role of which Latin played for a long time in the countries of Western Europe, the English national language, which received its literary design in the works of many writers, is increasingly being established.

\section{MATERIAL AND METHODS}

The lexicographic basis of the study is The Shorter Oxford English Dictionary on Historical Principles / Ed. Onions. L., 1968. Lexical units for linguistic analysis were selected by the method of continuous sampling, which in their semantics relate to words of an abstract philosophical nature. At the same time, the historical principle was observed, i.e. only the terminological vocabulary of the 16-17th centuries, inclusive, as it is recorded in the specified normative dictionary, fell under the lexical-semantic analysis. In addition, this vocabulary was checked against original sources - works of authors of this period.

\section{RESULTS}

The practical necessity of using the native language for the dissemination of new ideas and education, the language problems that arise before translators, the struggle with the supporters of Latin, who defend its right to be the only language of science and literary creativity - all this leads to attempts to theoretically substantiate the use of the native - English - language in ever more widespread. A conscious activity to improve the native language begins [4, p.180-186].

To establish general trends that comprehensively characterize the main composition of abstract philosophical vocabulary, it becomes necessary to trace the transformations determined by the time factor. New layers of vocabulary, both borrowed from Latin by means of the French language, and that existed earlier only in the 
everyday colloquial style, are included in the written literary language, with the help of which new concepts are expressed, a new interpretation of the semantics of lexical units, in the light of the established experimental system of Francis Bacon, "the true ancestor of all experimental science."

The enrichment of the language of the era with borrowings was due to powerful shifts in the entire social and political life of England during the Renaissance [5, p. 264]. Thinkers (poets, prose writers, playwrights), acting in various genres, each in their own way tried to explain the humanastudia of the era: poetry, prose, songs, verse dialogues, drama, political and scientific treatises, sermons, pamphlets, descriptions of travels $\neg$ viy, historical chronicles. A similar linguistic situation, when Latin dominated in such areas as science, political life, education, upbringing and religion, influenced the lexical composition and the totality of syntactic methods of organizing linguistic material of an abstract philosophical nature in various spheres and genres. The use of such vocabulary in the overwhelming majority of genres is one of the characteristic features of the literature of the era, since the new philosophy finds its expression in a new literary form - literaryrhetorical, designed for educated public circles, thereby including philosophicallyoriented works in the general flow of Latin literature, restoring its former ties with fiction, poetry, history, politics, rhetoric.

At the same time, the acquisition of new meanings by words that are characteristic of the expression of philosophical thought of shades indicates that there is a process of gradual professional differentiation of the philosophical language in connection with the specialization of knowledge, its shaping into a separate science (anticipation "anticipation", concurrence "coincidence" , gradation "gradation", etc.): "anticipation is when we prevent those wordes that another would saie" (T. Wilson. Rhet.100); "so shall my anticipation prevent your discovery" (Shaks. Haml. 11.2.304). Unambiguous words differ in insignificant frequency, but they have a high degree of semantic autonomy, independent of the context (modesty "modesty", presupposition "presupposition", ratiocination "reasoning"), "..is according to the light and preרsupposition of that which is delivered "-_" ... is in accordance with the clarity and presupposition of what is being said "(F.Bacon. Adv.L. 11.126); "withot any discourse of reason, or ratiocination" - "... without any discourse in reasons or reasoning" (Holland Plutarch, Mog. 1344); "..be pastime passing excellent, if it be ... with modesty" - "... to be great entertainment if it is connected ... with modesty" (Shaks.Ind.1.66).

There is a significant increase in the nest of word combinations from 2 to 32 lexical units while maintaining the main word as the nucleus of the combination and an increase in the number of lexical-semantic variants (LSV). These two conditions indicate a noticeable development of the semantic structure of words of a philosophical nature. The complication of the semantic structure of the analyzed words confirms the idea of their complete assimilation in the semantic sense [6, p. 182]. All interacting meanings of words play the role of clarifying, concretizing components of the primary borrowed meaning.

Etymologically, the abstract-philosophical vocabulary of the research period is divided into words: 1 ) arising from the native national vocabulary and 2) borrowed from other languages.

Some features of the introduction of new borrowed units into everyday life are noted: a) author's interpretations in dictionaries, where by their very nature simplicity and clarity of presentation are inherent; b) periphrases usually by descriptive translation or through the use of synonyms, for example: 
ratiocination is, that cometh of logic of any Commodity, or to echeve any discomodity, levity, lightnesse, inconstancie; - "an attempt to reasonably substantiate means to proceed from the logic of any convenience or ... to achieve any inconvenience, frivolity, superficial thinking, inconstancy."

In a significant number of cases, the author introduces a word without interpretation, counting on the linguistic erudition of the reader, while the context helps to determine the meaning of the introduced lexical unit: In the mysteries of the Christes person, there is no transition of the deitie into the humanite or humanite into the deitie - "In the mysteries of the person of Christ, there is no transition of deity into human form or vice versa" (Gard. Explication of transubstantiaton, 123). At the same time, one should distinguish between words that relate to philosophical vocabulary and express important, fundamental concepts of a given sphere (fact "fact", agent "agent", coherence "sequence", modesty "modesty", levity "gullibility"), from words that are philosophical terms in the analyzed period: ratiocination "reasoning", gradation "gradation", medium "medium", ubiquity "omnipresence", reflex "reflection", materiality "materiality", presupposition "assumption").

The manner of presentation in the first person was typical in the analyzed era (letters, sermons, pamphlets, poetry); this is confirmed by the predominance of personal active forms of the verb, which have a semantic shade of evaluation, the author's "I", as well as a personalized form of presentation (psalms, poetry, treatise), reflected in the selection of vocabulary, especially with verbs of physical action and with verbs "assessments, judgments, intentions" [7, p. 136]. These lexical units belong not only to scientific philosophical literature, but are also widely used in works of a very different genre: poetry, drama, treatises, sermons, correspondence, polemical articles, which allows us to conclude that in the period under study in On the whole, the abstract philosophical vocabulary has not yet been strictly limited within the framework of its terminological system, i.e. was not a "pure" belonging to philosophy, since the latter, as a new - Renaissance - was just being born, and therefore showed itself as a common vocabulary for expressing the philosophical thought of authors whose works are characterized by different genre orientations [8, p. 72-81]. This confirms the general historical tendency - the fact of the encyclopedic education of the representatives of the Renaissance and, accordingly, the various fields of application of their abilities.

\section{DISCUSSION}

Already in the XVI-XVII centuries, words of an abstract philosophical nature are used in various genres. This was facilitated by new philosophical thinking - the ideology of humanism, which became the philosophical thought of the era, because it was about the deepest revolution in the entire system of philosophical knowledge: the nature of philosophizing, style of thinking, the appearance of the philosopher himself, his place in society [9, $164 \mathrm{c}]$. This was especially noticeable in the field of ethics (modesty, levity, constancy, coherence), which expresses the moral and ethical qualities of a person and in the use of words with broad semantics (fact, gradation). The use of these groups of words is due to the fact that they are characterized by abstractness, are used mainly in the style of written speech (F. Bacon, C. Marlo, Shakespeare, T. Grafton, J. Milton, Stow, G. Fletcher, (ox) and characterizes the specifics of the new humanistic worldview of the intelligentsia, the increased social formalization of which was clearly indicated in the Renaissance. [10, p. 2672] The coup that began in this era meant, first of all, a change in the language of culture. The humanists oppose the professional language of medieval treatises with the elegance of the revived 
Latin speech, returning philosophy to a common literary culture - this is now required by the understanding of a philosophical text.

A number of words from the very beginning belong to the philosophical scientific terminology: reflex, ratiocination, anticipation, presupposition) [11, p. 627-631]. The scope of their distribution is very narrow - they are present in works of a philosophical nature (treatises, essays): "... great progress ever be made in science by means of anticipations" "... progress in science is always achieved with the help of anticipation (foresight) "(NO262); "by means of anticipation, that is to say, of the reasoning which is now in use" - "with the help of anticipation, that is, reasoning ..." (N.0.262); "presuppositions must seak assistance from similitudes and comparisons" - "assumptions should be based on similarities and comparisons" (F. Bacon. De Augm.V. 532).

In the analyzed texts, as the study has shown, usually microfield units are first attached to the term, i.e. a set of special lexical units combined with a given word within the term system, and later - words of the general literary language [12, p. 1969-1978]. For example, the compatibility of ratiocination in the first 100 years on the English soil: process of-; discourse of-; to evidence-, to evince-; reason or-. 15 lexical units - innovations of the Latin character are conjugated with words with similar (but not the same semantics): anticipation, coherence, correlation, elucidation, education, gradation, identity, levity, modesty, materiality, penalty, ratiocination, reflex, transition.These words, being an integral part of the English commonly used vocabulary (178 words in total), play the role of an intermediary in replenishing the reserves of the layer of abstract philosophical vocabulary. It is noteworthy that a certain number of conjugating words that arose within the same (16th) century stand out: hardheartedness "hardness (of thought)", falsity "fallibility", deceitfulness "deception"; perspicuity "clarity (of presentation)"; inclination "inclination"; reflection "reflection"; the vulgar "commoner"; forecast "foresight"; epitome "total". Observed in the English language of an older period and in the Middle Ages, the polysemantic semantics of these conjugate words, expressing a particular concept, in the 16 th century gives way to a clearer and more unambiguous expression of the concept, since the attitude towards the text has changed. We find this understanding in the fact that by cleansing the texts of ancient authors and Aristotle, first of all, from medieval "barbarisms", correcting the incorrect terminology that distorted the meaning of their teachings, humanists revived a true philosopher of antiquity, who could not be understood outside the general literary, historical, philosophical traditions. This is how the revived philosophical texts were perceived in a certain historical context and perspective of their time.

English abstract philosophical vocabulary acts as a multidimensional system characterized by the presence of numerous transitional cases, thus reflecting the complexity of the relationships and interconnections of the semantics of its constituent units. These words are also subject to processes that are characteristic of all Latin borrowings of the Renaissance. Thus, a philosophically focused vocabulary appears before us as a single, integral system, subordinate to certain objective laws of history and thinking, reflecting a really existing dialectical relationship and further development of the most important philosophical concepts, worldview of representatives of the era. It is significant that in the foreground is the part of the terms that is directly related to the central concepts of the philosophy of humanism (reflex, modesty, levity, identity, coherence, anticipation, education, correlation).

\section{CONCLUSION}


The Renaissance epoch most decisively influenced not only the content, but also the composition of the philosophical dictionary, as evidenced by the appearance in the studied era (XV-XVII centuries) of a large number of words to explain the concepts of a new worldview and worldview in the light of the revolutionary scientific discoveries of the era. The presence of philosophically "targeted" words among playwrights, poets, theologians suggests that their authors have mastered a new understanding of the world, and were also well acquainted with the main works of a philosophical nature of the old and new times, with the vocabulary used in such works.

\section{REFERENCES}

1. Rutenburg V.I. Renaissance Society. / / Renaissance Culture and Society. - M. .: Nauka, 1986. - p.3-7.

2. Akhundov M.D. The concept of space and time: origins, evolution, perspectives. - M., 1982.-222 p.

3. Konrad N.I. The Middle Ages in Historical Science. Fav. works. - M., 1975.-496 p.

4. Shaikhislamova Z.F. Ethno-mental aspects of the reconstruction of the worldview in the context of ethno-ontological interpretation // East-West: Interaction of languages and cultures. Sat. mater. III International Scientific Conference. 2015. p.180-186.

5. Shadmanov K. (2019). Formation of a new integral world outlook and English Renaissance philosophy of language: problems of comprehension of semiotic reality // Cross-Cultural Studies: Education and Science (CCS \& ES), vol. 4, Issue 11, June 2019, pp. 72-81.

6. Stupin L.P. The problem of normativity in the history of English lexicography in the $\mathrm{XY}$-XX centuries. - $\mathrm{L}$.: Publishing house of Leningrad State University, 1989. -164 p.
7. The Shorter Oxford English Dictionary on Historical Principles / Ed. Onions. L., 1968. pp. 2672.

8. Sadullaev D. B. Philosophical understanding of terms and concepts by an author as an object of linguistic investigations //Молодой ученый. - 2020. №. 22. - C. 627-631.

9. Sadullaev D. B. (2020). Historical reality concepts. ISJ Theoretical \& Applied Science, 04 (84), pp. 414- 419

10. Sadullaev Denis Bakhtiyorovich 2020. Concerning the history, formulation and interpretation of the conversion's issue in english language. International Journal on Integrated Education. 3, 3 (Mar. 2020), 9597. DOI:https://doi.org/10.31149/ijie.v3i3.96.

11. Sadullaev D. B., Ostonova S. N., Shodiev S. S. Interpretation of philosophical terms and concepts as an essential subject for linguistic researches of xix-xx centuries, held in Russia and Europe // ACADEMICIA: An International Multidisciplinary Research Journal. Year : 2020, Volume : 10, Issue : 10, First page: ( 590) Last page : (598), Online ISSN : 2249-7137. Article DOI : 10.5958/22497137.2020.01171.4

12. Sadullaev, Denis Bakhtiyorovich Terminology as a separate scientific field and its actual position in modern linguistics /I ACADEMICIA: An International Multidisciplinary Research Journal. Year : 2020, Volume : 10, Issue : 11, First page : ( 1964) Last page : (1973), Print ISSN : 00000000. Online ISSN : 2249-7137. Article DOI : 10.5958/2249-7137.2020.01486.X

13. Sadullaev, Denis B. "Problems of Understanding Philosophical Text as a Linguistic Phenomenon." JournalNX, vol. 6, no. 06, 2020, pp. 128-136.

14. Шадманов Курбан Бадриддинович, \& Садуллаев Денис Бахтиерович (2019). Из 
истории становления системы основных понятий английской философии. Наука и образование сегодня, (10 (45)), 40-43.

15. Садуллаев Д. Б. Форма существования языка //81.2 г (5У) Ш 16. - 2019. - С. 201.

16. Zarnigor Djalilova Obidovna Comparative Analysis Of Uzbek Men's And Women's Speech Through The Prism Of Gender Linguistics // Central asian journal of literature, philosophy and culture. - 2021. №2. - C. 22-26.

17. Zarnigor Djalilova Obidovna Studies on gender linguistics in the field of uzbek language // Academic research in educational sciences. - 2021. - №3..

18. Zarnigor Djalilova Obidovna concerning the issue of terms, having a place with various morphological classes (in view of the example of the terminological arrangement of social action) // New Day in Medicine. - 2020/12. - №(32). - C. 501-504.

19. Zarnigor Obidovna Jalilova ON THE FORMATION OF THE LANGUAGE OF SCIENTIFIC LITERATURE IN THE HISTORY OF THE ENGLISH LANGUAGE, E-Conference Globe, Bukhara State University, 2021/3/31

20. Sadullaev Denis Bakhtiyorovich Linguistic combinatory processes "assimilation" and "borrowing" as a basis for the development of modern english terminology // Asian Journal of Multidimensional Research (AJMR). Year : 2020, Volume : 9, Issue : 11, First page : (33) Last page : (38), Online ISSN : 2278-4853. Article DOI : $10.5958 / 2278$ 4853.2020.00297.9

21. Shahob Sharofitdinovich Shodiev. Academicia An International Multidisciplinary Research Journal "Interpretation of philosophical terms and concepts as an essential subject for linguistic researches of $x i x-x x$ centuries,held in Russia and Europe" 590-98 10.5958/2249-7137.2020.01171.4

22. 22. Shahobiddin Sharofiddinovich Shodiev. Bakaev Najmiddin Bakaevich. expressions.. (2020). The role of the Latin language in the history of world statehood. ISJ Theoretical \& Applied Science, 05 (85), 367-372. Soi: http://s-o-i.org/1.1/TAS-05-85-71 Doi: https://dx.doi.org/10.15863/TAS Scopus ASCC: 1203. THE ROLE OF THE LATIN LANGUAGE IN THE HISTORY OF WORLD STATEHOOD

23. Sh.Sh.Shodiyev.

N.B.Bakayev. M.N.Khafizova, S.N.Ostonova " SHAKESPEARS LEXICON: REASON WORD AS A DESIGN OF THE CONCEPT OF THE ABILITY OF THE HUMAN MIND TO ABSTRACTION, CONCLUSION " Theoretical and Applied Science, 162-166, 2020

24. Ш.Ш.Шодиев, А.Я.Шигабутдинова. «ШЕКСПИРОВСКИЙ ЛЕКСИКОН: СЛОВО REASON КАК ОБОЗНАЧАНИЕ ПОНЯТИЯ СПОСОБНОСТИ ЧЕЛОВЕЧЕСКОГО УМА К АБСТРАКЦИИ УМОЗАКЛЮЧЕНИЮ» Инновационный потенциал развития науки в современном мире, 189-197, 2020

25. Ostonova S. N. Spirituality and humanism of humanity in the era of Revival Vestnik Nauki I Obrazovaniya 2020. № 8 (86). Chast' 1 (Science and Education Gazette 2020. № 8 (86). Part 1).

26. Остонова, С. Н. National traditions and rituals in modern Uzbekistan (basing on the analysis of Uzbek traditional meal «Palov») / С. Н. Остонова. - Текст : непосредственный // Молодой ученый. 2020. — № 47 (337). — C. 199-203. — URL: https://moluch.ru/archive/337/75335/

27. Khakimova Mukhabbat and Nematova Zebo, "LEXICAL INNOVATIONS OF THE EARLY ENGLISH LANGUAGE PERIOD (XYI CENTURY)", IEJRD - International 
Multidisciplinary Journal, vol. 5, no. 9, p. 5, Dec. 2020.

28. Нематова, 3. T. Songs in teaching English to young second language learners / 3. T. Нематова, М. А. Хакимова. - Текст : непосредственный // Молодой ученый. 2020. — № 50 (340). — C. 497-499. — URL: https://moluch.ru/archive/340/76450/

29. Shahobiddin Sharofiddinivich Shodiev Islam in the evolution of social and political views of the Uzbek Jadids, their role in the formation of the idea of National Independence // CENTRAL ASIAN JOURNAL OF SOCIAL SCIENCES AND HISTORY. - Feb. 2021. - №VOLUME: 02 ISSUE: 02. - C. 45-50. 